\title{
Digestibilidades Ileal Aparente e Verdadeira dos Aminoácidos de Farinhas de Vísceras para Suínos ${ }^{1}$
}

\author{
Paulo Cesar Pozza², Paulo Cezar Gomes ${ }^{3}$, Juarez Lopes Donzele ${ }^{3}$, Horacio Santiago \\ Rostagno ${ }^{3}$, Magali Soares dos Santos Pozza², Darci Clementino Lopes ${ }^{3}$
}

RESUMO - O experimento foi conduzido com o objetivo de determinar as digestibilidades ileal aparente e verdadeira de cinco diferentes farinhas de vísceras. Foram utilizados 10 suínos mestiços, machos castrados, com peso inicial de 34,11 \pm 3,88 kg, previamente submetidos à cirurgia para implantação de cânula “T” simples. Os animais foram distribuídos em delineamento experimental de blocos ao acaso, com cinco tratamentos, quatro repetições e um animal por unidade experimental. Ao final das duas primeiras repetições, os mesmos animais foram redistribuídos e utilizados novamente nas repetições subseqüentes. Os tratamentos consistiram de uma dieta isenta de proteína à base de açúcar, amido, óleo e casca de arroz, tendo como única fonte protéica uma das cinco farinhas de vísceras. Os coeficientes de digestibilidade ileal aparente da lisina, treonina e metionina das diferentes farinhas de vísceras apresentaram variação de 63,40 a 74,01; 63,17 a 79,13 e 72,60 a 81,11\%, respectivamente, e os coeficientes de digestibilidade ileal verdadeiros apresentaram variação de 64,38 a 74,$88 ; 64,31$ a 80,60 e 73,07 a $81,64 \%$, respectivamente.

Palavras-chave: aminoácidos, digestibilidade ileal, farinha de vísceras, suínos

\section{Apparent and True Ileal Digestibilities of Poultry By-Products Amino Acids for Swine}

\begin{abstract}
The experiment was carried out with the objective of determining the apparent and true ileal digestibilities of amino acids from five different poultry by-product. Ten crossbreed swines, castrated males, averaging $31.11 \pm 3.88 \mathrm{~kg}$ were used in the experiment. The animals were previously submitted to the surgery for simple $\mathrm{T}$ canula implantation and, then, allotted to a randomized block design with five treatments, four replicates and one animal per experimental unit. At the end of the first and second replicates, these animals were allotted again to the treatments and used in the third and fourth replicates. The treatments consisted of a free protein diet based on sugar, starch, vegetable oil and rice peel and one of the five poultry by-product as protein source in the diet. The coefficients of apparent ileal digestibility of lysine, threonine and methionine of different poultry by-product ranged from 63.40 to $74.01,63.17$ to 79.13 and 72.60 to $81.11 \%$, respectively, and the coefficients of true ileal digestibility, from 64.38 to $74.88,64.31$ to 80.60 and 73.07 to $81.64 \%$, respectively.
\end{abstract}

Key Words: amino acids, ileal digestibility, poultry by-product, swine

\section{Introdução}

Entre os alimentos protéicos mais utilizados na alimentação de suínos encontra-se o farelo de soja. Entretanto, os subprodutos de abatedouro aparecem como alternativa na formulação de rações para suínos. Dos subprodutos provenientes do abate de aves, as farinhas de vísceras têm sido utilizadas como alternativa protéica na substituição parcial do farelo de soja em rações para monogástricos (Pereira, 1993). Atualmente, milhões de toneladas de subprodutos animais são produzidos pelas indústrias e se esse material não for reciclado em rações animais, passam a ser considerados resíduos industriais, causando enorme perda econômica para os setores industriais de processamento de subprodutos, além de sérios danos ao meio ambiente (Vieites, 2000).
Na literatura, os valores relativos à composição química das farinhas de vísceras indicam grande variabilidade no conteúdo protéico e na composição dos aminoácidos. Por outro lado, a utilização racional dos alimentos e de seus subprodutos na alimentação de suínos depende, basicamente, dos conhecimentos obtidos pela análise proximal, dos valores de digestibilidade e de disponibilidade dos nutrientes e do desempenho dos animais (Ferreira et al., 1997).

No caso dos aminoácidos, os valores de digestibilidade são melhor caracterizados pela quantidade absorvida até o final do íleo, uma vez que os não absorvidos nesta parte do intestino são degradados por microrganismos a diferentes taxas no intestino grosso. A digestibilidade aparente de aminoácidos, baseada nas avaliações realizadas no íleo distal de

\footnotetext{
1 Parte da Dissertação de Doutorado do primeiro autor financiada pela FAPEMIG.

2 Professor do curso de Zootecnia/UNIOESTE.

3 Professor do Departamento de Zootecnia/UFV. Bolsista do CNPq.
} 
suínos, não é corrigida para as perdas endógenas de aminoácidos. Deve-se ressaltar que existem perdas substanciais de proteínas endógenas. Portanto, as perdas endógenas de aminoácidos são consideradas na determinação da digestibilidade ileal verdadeira de aminoácidos (Caine, 1997).

Objetivou-se determinar os valores de aminoácidos digestíveis aparentes e verdadeiros de diferentes farinhas de vísceras para suínos.

\section{Material e Métodos}

O experimento foi realizado no Setor de Suinocultura do Departamento de Zootecnia da Universidade Federal de Viçosa

Foram utilizados 10 suínos mestiços (Landrace $\mathrm{x}$ Large White), machos castrados, previamente submetidos à cirurgia para implantação de cânula "T" simples. Após o período de recuperação (20 dias), os animais com peso inicial de 34,11 $\pm 3,88 \mathrm{~kg}$ foram submetidos aos tratamentos, permanecendo em baias de creche, metálicas, suspensas, providas de pisos plásticos e laterais teladas, dotadas de comedouros semi-automáticos e bebedouros tipo chupeta, localizadas em prédio de alvenaria com piso de concreto, teto de madeira e janelas basculantes nas laterais.

No interior das instalações, foi utilizado um termômetro de mínima e máxima à altura dos animais para que fossem registradas, duas vezes ao dia, as leituras das temperaturas durante o período experimental. As temperaturas máxima e mínima do interior das instalações, durante a condução do experimento, foram de $26,69 \pm 1,29$ e $21,67 \pm 1,51^{\circ} \mathrm{C}$, respectivamente.

O delineamento experimental foi o de blocos ao acaso, com cinco tratamentos e quatro repetições. Ao término das duas primeiras repetições, os mesmos animais foram reutilizados nas repetições subseqüentes, sendo redistribuídos nos tratamentos para evitar que o mesmo animal recebesse a mesma dieta em duas repetições consecutivas.

Os tratamentos constaram de cinco rações isoprotéicas (Tabela 1), formuladas à base de amido de milho, açúcar, casca de arroz, minerais, vitaminas e cinco partidas de farinhas de vísceras (FV1, FV2, FV3, FV4 e FV5), fornecidas por cinco fabricantes diferentes. A casca de arroz foi utilizada de modo que os tratamentos apresentassem 2,00\% de fibra bruta. $\mathrm{Na}$ formulação das rações, foram considerados os valores de composição química e energia digestível das diferentes farinhas de vísceras obtidos por Pozza (2001).

A casca de arroz, utilizada como fonte de fibra, foi separada dos grãos de arroz quebrados, dos remanescentes ainda dentro da casca e das impurezas contidas na palha, por meio de ventilador. As rações experimentais continham $0,5 \%$ de óxido crômico $\left(\mathrm{Cr}_{2} \mathrm{O}_{3}\right)$, utilizado como indicador na determinação da digestibilidade.

A quantidade de ração fornecida diariamente a cada animal foi calculada com base no tamanho metabólico $\left(\mathrm{kg}^{0,75}\right)$. Para evitar perdas e facilitar a ingestão, as rações foram umedecidas na proporção de 75 mL de água para 100 g de ração, fornecidas duas vezes ao dia (7 e 19h).

Foi adotado um período de cinco dias de adaptação aos tratamentos e um dia de coleta, ressaltando-se que as coletas tiveram início às $7 \mathrm{~h}$ e término às $7 \mathrm{~h}$ do dia seguinte, sendo realizadas em intervalos de 3 horas.

As amostras de digesta foram coletadas em sacos de polietileno presos à cânula e, posteriormente, colocadas em sacos plásticos, sendo identificadas e armazenadas em congelador $\left(-5^{\circ} \mathrm{C}\right)$ até o final do período de coleta. Ao final do período, as amostras provenientes de cada animal foram descongeladas, pesadas, homogeneizadas e liofilizadas.

As análises laboratorais foram realizadas no Laboratório de Nutrição Animal do Departamento de Zootecnia da Universidade Federal de Viçosa. Foram determinados os teores de matéria seca, proteína bruta e cromo das digestas e rações experimentais, de acordo com as técnicas descritas por Silva (1990). A composição em aminoácidos das digestas e dos alimentos foram realizadas no Laboratório de Nutrição Animal do Departamento de Zootecnia da Universidade Federal de Viçosa e na Ajinomoto Biolatina Ind. e Com. Ltda., por meio de cromatografia de troca iônica.

Na determinação dos valores de digestibilidade ileal verdadeira, foram utilizados os valores de perdas endógenas dos aminoácidos, obtidos por Pozza (2001), em uma dieta isenta de proteína contendo $2 \%$ de fibra bruta. A determinação da digestibilidade ileal dos aminoácidos foi calculada com base nos níveis de crômio (Cr) nas rações e fezes dos suínos, por meio do cálculo do fator de indigestibilidade (Rostagno \& Featherston, 1977).

Como procedimento estatístico, utilizou-se o teste de comparação de médias Student Newman-Keuls, a $5 \%$ de probabilidade, entre os valores médios dos 
Tabela 1 - Composição centesimal das rações experimentais

Table 1 - Composition (\%) of experimental diets

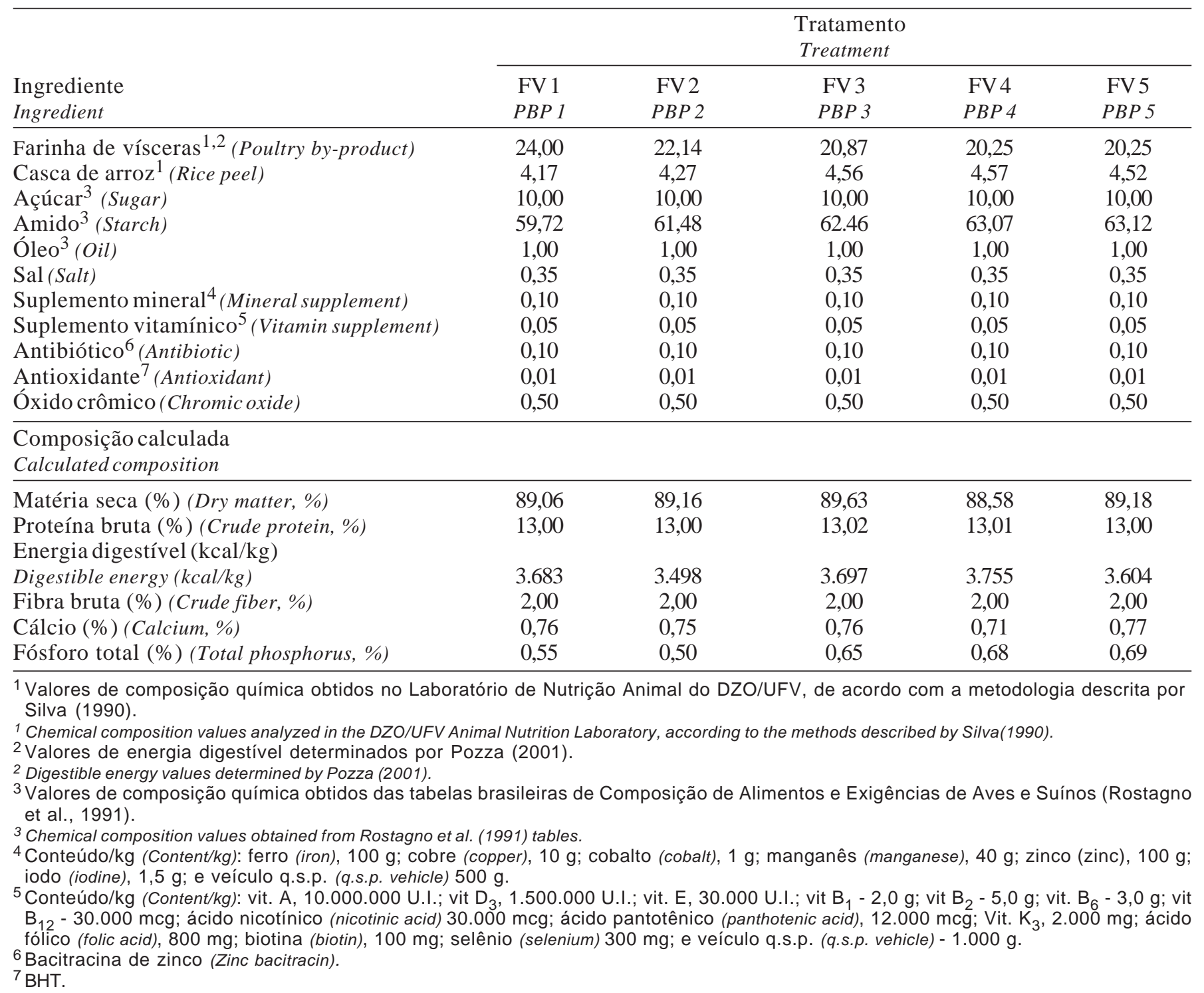

coeficientes de digestibilidades aparente e verdadeira dos aminoácidos, utilizando-se o programa SAEG (UFV, 1999).

\section{Resultados e Discussão}

Os valores de aminoácidos totais das farinhas de vísceras são apresentados na Tabela 2. Constatou-se variação de 2,68 a 3,37\% da lisina total, referente às farinhas de vísceras com 52,77 e 62,47\% de proteína bruta. Estes resultados tiveram maior variabilidade quando comparados aos valores propostos por Rostagno et al. (2000) para as farinhas de vísceras com 58,00 e 55,20\% de proteína bruta que apresentaram 3,24 e 3,09\% de lisina total, respectivamente. Os valores de lisina total foram superiores aos propostos por Rhône Poulenc (1993) e Afz et al.(2000), de 2,41 e 2,42\%, para farinhas de vísceras com 58,00 e $57,00 \%$ de proteína bruta, respectivamente. Por outro lado, o valor de 3,32\% de lisina total apresentado pelo NRC (1998) para a farinha de vísceras contendo $64,1 \%$ de proteína bruta é similar ao obtido com a farinha de vísceras 4 (FV 4) deste trabalho.

Entre os aminoácidos avaliados, o ácido glutâmico foi o encontrado, em média, em maior quantidade em todas as amostras de farinha de vísceras, o que está de acordo com os resultados relatados por Afz et al. (2000), em que o ácido glutâmico foi o aminoácido de maior quantidade entre os aminoácidos essenciais e não-essenciais. 
Tabela 2 - Composição em aminoácidos totais e proteína bruta (PB) das diferentes farinhas de vísceras, em porcentagem da matéria natural ${ }^{1}$

Table 2 - Total amino acid and crude protein (CP) composition of the different poultry by-products, as-fed basis ${ }^{1}$

\begin{tabular}{|c|c|c|c|c|c|}
\hline & & & $\begin{array}{l}\text { la de ví } \\
\text { ltry by-p }\end{array}$ & & \\
\hline & 1 & 2 & 3 & 4 & 5 \\
\hline Lisina (Lysine) & 2,679 & 2,763 & 3,176 & 3,373 & 3,092 \\
\hline Metionina (Methionine) & 0,837 & 1,038 & 1,255 & 1,104 & 1,095 \\
\hline Treonina (Threonine) & 1,782 & 1,916 & 2,705 & 2,314 & 2,043 \\
\hline Histidina (Histidine) & 0,971 & 1,002 & 1,223 & 1,034 & 1,094 \\
\hline Valina(Valine) & 2,187 & 2,211 & 3,647 & 2,596 & 2,322 \\
\hline Isoleucina (Isoleucine) & 1,581 & 1,694 & 2,757 & 2,033 & 1,988 \\
\hline Leucina (Leucine) & 2,972 & 3,199 & 4,920 & 3,743 & 3,388 \\
\hline Fenilal.(Phenylalanine) & 1,795 & 1,787 & 2,748 & 2,202 & 1,987 \\
\hline Cistina (Cystine) & 0,428 & 0,642 & 1,041 & 0,640 & 0,749 \\
\hline Serina (Serine) & 1,993 & 1,915 & 3,462 & 2,561 & 2,437 \\
\hline Tirosina (Tyrosine) & 1,016 & 1,099 & 1,953 & 1,332 & 1,234 \\
\hline
\end{tabular}

${ }^{1}$ Análises realizadas no Laboratório de Nutrição Animal (DZO - UFV) e na Ajinomoto Ind. e Com. Ltda.

${ }^{1}$ Analyses carried out at the Animal Nutrition Laboratory (DZO - UFV), and Ajinomoto Ind. e Com. Ltda.

Essa variação no conteúdo de aminoácidos totais das diferentes amostras de farinhas de vísceras pode ser decorrente das diferenças entre os materiais utilizados no processamento. Seerley (1991) relatou que os alimentos protéicos de origem animal podem apresentar maior variação que o farelo de soja. Segundo a Associação Nacional dos Fabricantes de Rações ANFAR - (1985), a farinha de vísceras de aves é o produto resultante da cocção de vísceras de aves, sendo permitida a inclusão de cabeças e pés, não devendo conter penas e outros componentes estranhas à sua composição, salvo naquelas quantidades inevitáveis aos bons métodos de processamento. Entretanto, a literatura não especifica as proporções de cada componente permitidas no processamento.

Os coeficientes de digestibilidades ileal aparente e verdadeira dos aminoácidos das diferentes farinhas de vísceras estudadas encontram-se nas Tabelas 3 e 4.

Os coeficientes de digestibilidade ileal aparente obtidos para a lisina foram inferiores aos apresentados por Knabe et al. (1989), que avaliaram quatro diferentes amostras de farinha de vísceras utilizando suínos submetidos à cirurgia de implantação de cânula “T” e obtiveram valor mínimo de $84 \%$ para a farinha de vísceras com 64\% de proteína bruta. Os valores obtidos neste estudo, embora inferiores, foram próxi- mos aos 76\% propostos por Rhône Poulenc (1993) para a digestibilidade ileal aparente da lisina.

Os resultados econtrados para a metionina são superiores ao apresentado por Rhône Poulenc (1993) e NRC (1998), que propuseram coeficiente de digestibilidade ileal aparente de $74 \%$, superior apenas ao da farinha de vísceras 3 (FV 3).

Observou-se coeficiente de digestibilidade ileal aparente médio de 73,29\% para treonina, ou seja, intermediário aos valores médios de $75 \%$, obtido por Knabe et al. (1989), e de 72\%, proposto por Rhône Poulenc (1993) e pelo NRC (1998). Para a farinha de vísceras 3 (FV 3), o coeficiente de digestitilidade ileal aparente foi de $63,17 \%$ para a treonina, inferior aos valores médios descritos na literatura.

Os coeficientes de digestibilidade ileal aparente da arginina foram de 80,82 a $88,27 \%$, para as farinhas de vísceras 3 e 4, respectivamente. O NRC (1998) propõe coeficiente intermediário (85\%) aos valores obtidos neste estudo. Ao avaliarem quatro farinhas de vísceras, Knabe et al. (1989) obtiveram variação de 85,00 a $90,00 \%$ entre os coeficientes de digestibilidade ileal aparente da arginina (média de $88,00 \%$ ), sendo superior ao valor médio de $85,28 \%$ encontrado neste trabalho.

A média dos coeficientes de digestibilidade ileal aparente obtidos para a valina foi de $67,11 \%$, mostrando-se 
Tabela 3 - Coeficientes de digestibilidade ileal aparente ${ }^{1}$ dos aminoácidos das diferentes farinhas de vísceras Table 3 - Apparent ileal digestibility coefficients ${ }^{1}$ from different poultry by-products

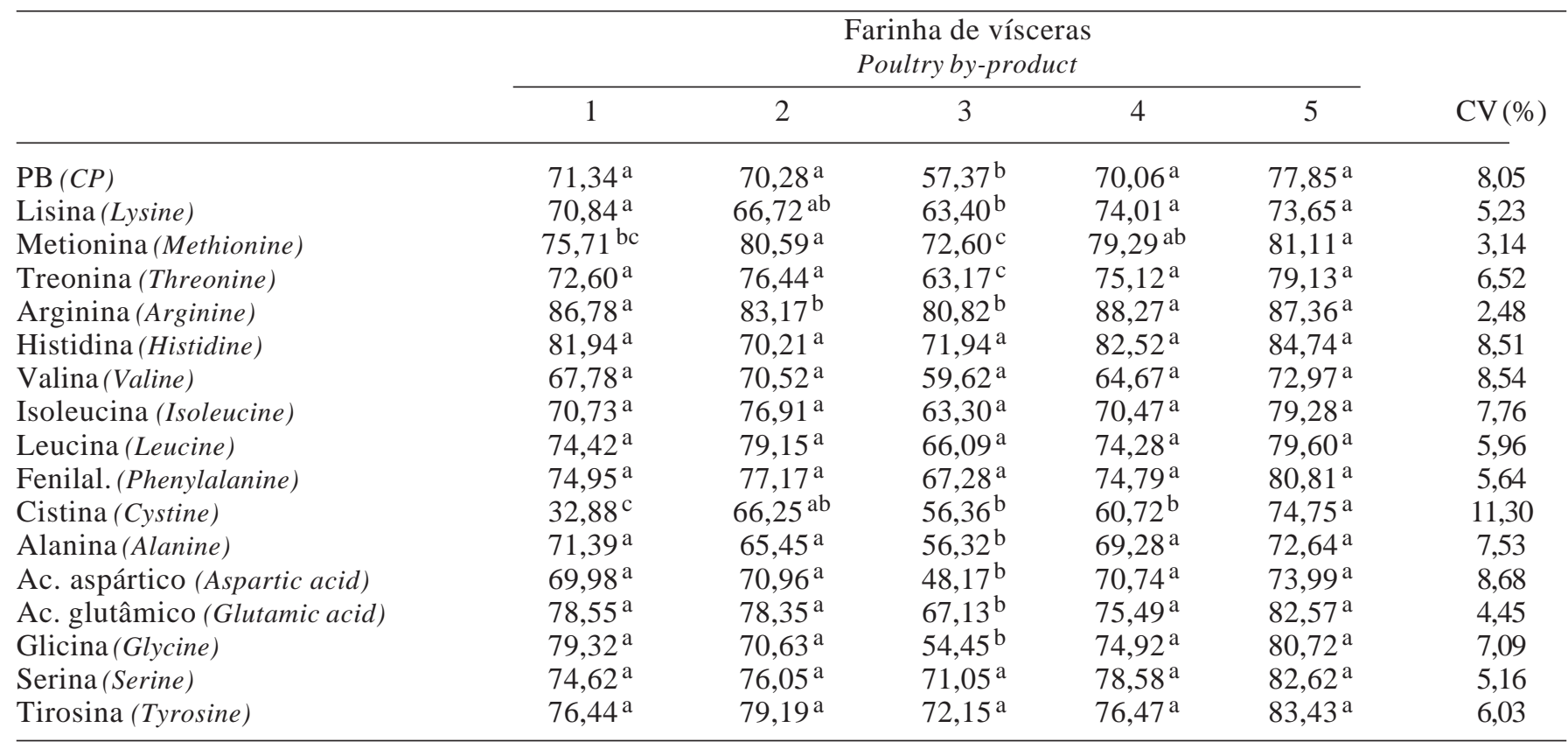

1 Valores na mesma linha, com letras distintas, são diferentes $(P<0,05)$ pelo teste Student Newman Keuls.

1 Values in the same row, followed by different letters, differ $(P<0.05)$, Student Newman Keuls Test.

Tabela 4 - Coeficientes de digestibilidade ileal verdadeira ${ }^{1}$ dos aminoácidos das diferentes farinhas de vísceras Table 4 - True ileal digestibility coefficients of amino acids from different poultry by-product

\begin{tabular}{|c|c|c|c|c|c|c|}
\hline & \multicolumn{5}{|c|}{$\begin{array}{c}\text { Farinha de vísceras } \\
\text { Poultry by-product }\end{array}$} & \multirow[b]{2}{*}{$\mathrm{CV}(\%)$} \\
\hline & 1 & 2 & 3 & 4 & 5 & \\
\hline $\mathrm{PB}(C P)$ & $72,39^{a}$ & $71,24^{\mathrm{a}}$ & $58,31^{b}$ & $70,93^{a}$ & $78,75^{a}$ & 7,72 \\
\hline Lisina (Lysine) & $71,97^{\mathrm{a}}$ & $67,8^{a b}$ & $64,38^{b}$ & $74,88^{\mathrm{a}}$ & $74,64^{\mathrm{a}}$ & 5,16 \\
\hline Metionina (Methionine) & 76,39 bc & $81,14^{\mathrm{a}}$ & $73,07^{\mathrm{c}}$ & $79,80^{\mathrm{ab}}$ & $81,64^{\mathrm{a}}$ & 3,12 \\
\hline Histidina (Histidine) & $82,58^{a}$ & $70,83^{\mathrm{a}}$ & $72,47^{\mathrm{a}}$ & $83,11^{\mathrm{a}}$ & $85,32^{a}$ & 8,45 \\
\hline Valina(Valine) & $69,16^{\mathrm{a}}$ & $71,89^{\mathrm{a}}$ & $60,47^{\mathrm{a}}$ & $65,81^{\mathrm{a}}$ & $74,29^{a}$ & 8,39 \\
\hline Isoleucina (Isoleucine) & $71,94^{\mathrm{a}}$ & $78,03^{\mathrm{a}}$ & $64,02^{\mathrm{a}}$ & $71,39^{\mathrm{a}}$ & $80,25^{a}$ & 7,66 \\
\hline Leucina (Leucine) & $75,41^{\mathrm{a}}$ & $80,07^{\mathrm{a}}$ & $66,71^{\mathrm{a}}$ & $75,06^{\mathrm{a}}$ & $80,48^{a}$ & 5,89 \\
\hline Fenilal.(Phenylalanine) & $75,91^{\mathrm{a}}$ & $78,13^{a}$ & $67,93^{\mathrm{a}}$ & $75,56^{\mathrm{a}}$ & $81,69^{a}$ & 5,58 \\
\hline Cistina (Cystine) & $35,76^{\mathrm{c}}$ & $68,17^{\mathrm{ab}}$ & $57,59^{b}$ & $62,61^{\mathrm{c}}$ & $76,42^{\mathrm{a}}$ & 10,94 \\
\hline Glicina(Glycine) & $80,11^{\mathrm{a}}$ & $71,82^{\mathrm{a}}$ & $55,78^{b}$ & $75,71^{\mathrm{a}}$ & $81,62^{\mathrm{a}}$ & 7,00 \\
\hline Serina (Serine) & $75,52^{\mathrm{a}}$ & $76,98^{\mathrm{a}}$ & $71,59^{a}$ & $79,27^{\mathrm{a}}$ & $83,36^{\mathrm{a}}$ & 5,11 \\
\hline Tirosina (Tyrosine) & $77,44^{\mathrm{a}}$ & $80,11^{\mathrm{a}}$ & $72,69^{a}$ & $77,22^{\mathrm{a}}$ & $84,27^{\mathrm{a}}$ & 5,97 \\
\hline
\end{tabular}

${ }^{1}$ Valores na mesma linha, com letras distintas, diferem a $5 \%$ de significância pelo teste de Student Newman Keuls.

${ }^{1}$ Values in the same row, followed by different letters, differ $(P<0.05)$, Student Newman Keuls Test. 
inferior às médias propostas por Rhône Poulenc (1993) e NRC (1998), de 71,00 e 74,00\%, respectivamente, ressaltando-se que os coeficiente para as farinhas de vísceras 2 e 5 foram os que mais se aproximaram desses valores. Valor médio de $80,00 \%$ foi apresentado por Knabe et al. (1989), que atribuíram os altos valores de digestibilidade ileal aparente dos aminoácidos das farinhas de vísceras ao material utilizado e ao processamento térmico, entre outros fatores.

Quanto à variabilidade verificada entre os coeficientes de digestibilidade aparente, observou-se que, de modo geral, a farinha de vísceras 5 (62,46\% de proteína bruta), apresentou maiores coeficientes de digestibilidade que as demais. Pode-se observar ainda que as farinhas de vísceras, com valores próximos de proteína bruta, apresentaram diferenças entre os coeficientes de digestibilidade ileal aparente, o que está de acordo com os dados reportados por Knabe et al. (1989), que obtiveram maiores coeficientes de digestibilidade ileal aparente à medida que as amostras de farinhas de vísceras apresentaram maiores quantidades de proteína bruta. No entanto, para alguns aminoácidos, como treonina, triptofano e leucina, os autores obtiveram diferentes coeficientes entre amostras de farinhas de vísceras com o mesmo conteúdo protéico. Por outro lado, a variação do conteúdo de proteína bruta de quatro amostras de farinhas de vísceras estudadas pelos autores foi inferior (63,80 a 65,20\%) à obtida neste estudo.

Os coeficientes de digestibilidade ileal verdadeira da lisina das farinhas de vísceras 4 e 5 foram próximos ao valor de 77,00\% apresentado por Afz et al. (2000), porém, inferiores ao de 80,00\% proposto pelo NRC (1998), indicando que as farinhas de vísceras 1, 2 e 3 apresentaram coeficientes inferiores aos propostos na literatura.

O coeficiente de digestibilidade ileal verdadeira da metionina, em média, foi de 78,41\%, que é intermediário aos valores propostos pelo NRC (1998) e por Afz et al. (2000), de 80,00 e 77,00\%, respectivamente.

Por outro lado, observou-se que o coeficiente de digestibilidade ileal verdadeira da treonina, em média, foi de 74,71\%, próximo aos 76,00 e 77,00\% apresentados por Rhône Poulenc (1993) e Afz et al. (2000), respectivamente. No entanto, nas farinhas de vísceras 3 e 5 , foram registrados os valores mais discrepantes em relação à literatura, obtendo-se, respectivamente, coeficientes de digestibilidade ileal verdadeira de 64,31 e $80,60 \%$.

Constatou-se também variabilidade entre os coeficientes de digestibilidade ileal verdadeira dos demais aminoácidos estudados e, entre os quais, a arginina apresentou variação de 81,20 a $87,75 \%$, com valor médio de $85,68 \%$, semelhante aos $85,00 \%$ propostos por Rhône Poulenc (1993) e pelo NRC (1998). Quanto à valina, foi obtido coeficiente de digestibilidade ileal verdadeira de $68,32 \%$, em média, sendo inferior aos 74,00\% apresentados na literatura.

As diferenças entre os coeficientes de digestibilidade dos aminoácidos, além de serem influenciadas pela composição da matéria-prima utilizada, podem ainda ser decorrentes do processamento térmico ao qual as farinhas de vísceras foram submetidas. Stangeland (1997) afirmou que o processamento a altas temperaturas e, em alguns casos, o longo tempo de processamento têm efeito adverso sobre a digestibilidade de aminoácidos em subprodutos de origem animal. Varnish \& Carpenter (1975), estudando o efeito da autoclavagem de tecidos protéicos de aves, observaram modificação na estrutura da proteína, de modo que a ação das enzimas, associada à digestão, foi prejudicial. No entanto, a literatura tem postulado reações que envolvem o grupamento e-amino da lisina e os grupos carboxil $\left(\mathrm{CO}-\mathrm{NH}_{2}\right)$ dos ácidos aspártico e glutâmico (Bjarnason \& Carpenter, 1970).

Entre os aminoácidos essenciais, a treonina apresentou grandes diferenças entre os coeficientes de digestibilidade ileal aparente e verdadeira, em todas as farinhas de vísceras avaliadas. Segundo Li et al. (1994) essa diferença está associada à baixa digestibilidade aparente da treonina, em razão de sua alta concentração nas secreções endógenas.

Os valores de aminoácidos digestíveis aparentes e verdadeiros das diferentes amostras de farinhas de vísceras estão apresentados nas Tabelas 5 e 6 .

O conteúdo de aminoácidos digestíveis aparentes e verdadeiros é resultado de seus respectivos coeficientes de digestibilidade e do conteúdo de aminoácidos totais. Pode-se notar a expressiva diferença entre o conteúdo de aminoácidos digestíveis aparentes e verdadeiros em relação ao conteúdo de aminoácidos totais. Essa diferença deve ser considerada na formulação de dietas para suínos, uma vez que a literatura dispõe de valores de exigência em aminoácidos digestíveis (NRC, 1998; Rostagno et al., 2000). Fuller \& Wang (1990) salientaram que a formulação de dietas com base nos aminoácidos digestíveis é mais precisa, visto que a digestibilidade dos aminoácidos varia entre os principais ingredientes utilizados na alimentação dos suínos. 
Tabela 5 - Composição em aminoácidos digestíveis aparentes das farinhas de vísceras, em porcentagem da matéria natural

Table 5 - Apparent digestible amino acid composition of the poultry by-products, as-fed basis

\begin{tabular}{lccccc}
\hline $\begin{array}{l}\text { Aminoácido (\%) } \\
\text { Amino acid (\%) }\end{array}$ & \multicolumn{5}{c}{$\begin{array}{c}\text { Farinha de vísceras } \\
\text { Poultry by-product }\end{array}$} \\
\cline { 2 - 6 } & \multicolumn{7}{c}{2} & 3 & 4 & 5 \\
\hline Lisina (Lysine) & 1,90 & 1,84 & 2,01 & 2,50 & 2,28 \\
Metionina (Methionine) & 0,63 & 0,84 & 0,91 & 0,88 & 0,89 \\
Treonina (Threonine) & 1,29 & 1,46 & 1,71 & 1,74 & 1,62 \\
Arginina (Arginine) & 3,17 & 2,65 & 3,26 & 3,63 & 3,30 \\
Histidina (Histidine) & 0,80 & 0,70 & 0,88 & 0,85 & 0,93 \\
Valina(Valine) & 1,48 & 1,56 & 2,17 & 1,68 & 1,69 \\
Isoleucina (Isoleucine) & 1,12 & 1,30 & 1,75 & 1,43 & 1,58 \\
Leucina (Leucine) & 2,21 & 2,53 & 3,25 & 2,78 & 2,70 \\
Fenilal. (Phenylalanine) & 1,35 & 1,38 & 1,85 & 1,65 & 1,61 \\
Cistina (Cystine) & 0,14 & 0,43 & 0,59 & 0,39 & 0,56 \\
Alanina (Alanine) & 2,45 & 1,92 & 1,92 & 2,49 & 2,43 \\
Ac. aspártico (Aspartic acid) & 2,67 & 2,74 & 2,25 & 3,24 & 3,08 \\
Ac. glutâmico (Glutamic acid) & 4,77 & 4,62 & 5,40 & 5,39 & 5,58 \\
Glicina (Glycine) & 4,70 & 2,80 & 1,99 & 4,39 & 4,28 \\
Serina (Serine) & 1,49 & 1,46 & 2,46 & 2,01 & 2,01 \\
Tirosina (Tyrosine) & 0,78 & 0,87 & 1,41 & 1,02 & 1,03 \\
\hline
\end{tabular}

Tabela 6 - Composição em aminoácidos digestíveis verdadeiros das farinhas de vísceras, em porcentagem da matéria natural

Table 6 - True digestible amino acid composition of the poultry by-products, as-fed basis

\begin{tabular}{lccccc}
\hline \multirow{2}{*}{$\begin{array}{l}\text { Aminoácido (\%) } \\
\text { Amino acid (\%) }\end{array}$} & \multicolumn{5}{c}{$\begin{array}{c}\text { Farinha de vísceras } \\
\text { Poultry by-product }\end{array}$} \\
\cline { 2 - 6 } & 1 & 2 & 3 & 4 & 5 \\
\hline Lisina (Lysine) & 1,93 & 1,87 & 2,04 & 2,53 & 2,31 \\
Metionina (Methionine) & 0,64 & 0,84 & 0,92 & 0,88 & 0,89 \\
Treonina (Threonine) & 1,32 & 1,49 & 1,74 & 1,77 & 1,65 \\
Arginina (Arginine) & 3,18 & 2,66 & 3,27 & 3,64 & 3,31 \\
Histidina (Histidine) & 0,80 & 0,71 & 0,89 & 0,86 & 0,93 \\
Valina(Valine) & 1,51 & 1,59 & 2,21 & 1,71 & 1,73 \\
Isoleucina (Isoleucine) & 1,14 & 1,32 & 1,77 & 1,45 & 1,60 \\
Leucina(Leucine) & 2,24 & 2,56 & 3,28 & 2,81 & 2,73 \\
Fenilal.(Phenylalanine) & 1,36 & 1,40 & 1,87 & 1,66 & 1,62 \\
Cistina (Cystine) & 0,15 & 0,44 & 0,60 & 0,40 & 0,57 \\
Alanina (Alanine) & 2,49 & 1,96 & 1,96 & 2,53 & 2,48 \\
Ac. aspártico (Aspartic acid) & 2,71 & 2,78 & 2,29 & 3,28 & 3,12 \\
Ac. glutâmico (Glutamic acid) & 4,81 & 4,66 & 5,45 & 5,44 & 5,62 \\
Glicina(Glycine) & 4,75 & 2,84 & 2,04 & 4,43 & 4,33 \\
Serina (Serine) & 1,51 & 1,47 & 2,48 & 2,03 & 2,03 \\
Tirosina (Tyrosine) & 0,79 & 0,88 & 1,42 & 1,03 & 1,04 \\
\hline
\end{tabular}




\section{Conclusões}

As farinhas de vísceras apresentaram variação de 63,40 a 74,01; 63,17 a 79,13 e 72,60 a 81,11\% entre os coeficientes de digestibilidade ileal aparente da lisina, treonina e metionina. Os coeficientes de digestibilidade ileal verdadeira desses aminoácidos apresentaram variação de 64,38 a 74,88; 64,31 a 80,60 e 73,07 a $81,64 \%$, respectivamente, devendo-se, na formulação de rações, utilizar os valores de aminoácidos digestíveis verdadeiros das farinhas de vísceras.

\section{Literatura Citada}

AFZ, AJINOMOTO EUROLYSINE, AVENTIS ANIMAL NUTRITION, INRA, ITCF. Digestibilidade ileal estandarizada de aminoácidos em ingredientes para rações de suínos. 2000. 44p. (Ami Pig)

ASSOCIAÇÃO NACIONAL DOS FABRICANTES DE RAÇÕES - ANFAR. Matérias-primas para alimentação animal. 4 ed. São Paulo: 1985. 65p.

BJARNASON, J.; CARPENTER, K.J. Mechanisms of heat damage in proteins. 2. Chemical changes in pure protein. British Journal Nutrition, v.24, p.313-329, 1970.

CAINE, W.R. Ileal recovery of endogenous amino acids in pigs. Wageningen: Wageningen Agricultural University, 1997. 169p. (PhD Thesis) - Wageningen Agricultural University, 1997.

FERREIRA, E.R.A.; FIALHO, E.T.; TEIXEIRA, A.S. et al. Avaliação da composição química e determinação de valores energéticos e equação de predição de alguns alimentos para suíno Revista Brasileira de Zootecnia, v.26, n.3, p.514523, 1997.

FULLER, M.F., WANG, T.C. Digestible ideal protein: a measure of dietary protein value. Pig News and Information, v.11, p.353-357, 1990.

KNABE, D.A.; LA RUE, E.J.; GREGG, E.J. Apparent digestibility of nitrogen and amino acids in protein feedstuffs by growing pigs. Journal of Animal Science, v.67, p.441-458, 1989.

LI, S., SAUER, W.C., HARDIN, R.T. Effect of dietary fibre level on amino acid digestiblility in young pigs. Journal of Animal Science, v.74, p.327-333, 1994.

NATIONAL RESEARCH COUNCIL - NRC. Nutrients requirement of swine. 10.ed. Washington, D.C.: National Acedemy of Science, 1998. 189p.
PEREIRA, L.E.T. Farinha de vísceras de aves em substituição ao farelo de soja na alimentação de suínos em crescimento e terminação. Viçosa, MG: Universidade Federal de Viçosa, 1993. 30p. Dissertação (Mestrado em Zootecnia) - Universidade Federal de Viçosa, 1993.

POZZA, P.C. Valor energético e digestibilidade ileal de aminoácidos de farinha de carne e ossos e de farinha de vísceras para suínos. Viçosa, MG: Universidade Federal de Viçosa, 2001.79p. Tese (Doutorado em Zootecnia) - Universidade Federal de Viçosa, 2001.

RHÔNE POULENC. Rhodimet feed formulation guide. 6.ed. France, 1993. 39p. (Rhône-Poulenc Animal Nutrition).

ROSTAGNO, H.S.; FEATHERSTON, W.R. Estudos de métodos para determinação de disponibilidade de aminoácidos. Revista da Sociedade Brasileira de Zootecnia, v.6, n.1, p.64-75, 1977.

ROSTAGNO, H.S.; SILVA, D.J.; COSTA, P.M.A. et al. Composição de alimentos e exigências nutricionais de aves e suínos (tabelas brasileiras). 1.ed. Viçosa, MG: Universidade Federal de Viçosa, 1991. 61p.

ROSTAGNO, H.S.; ALBINO, L.F.T.; DONZELE, J.L. et al. Tabelas brasileiras para aves e suínos: composição de alimentos e exigências nutricionais. 1.ed. Viçosa, MG: Universidade Federal de Viçosa, 2000. 141p.

SEERLEY, R.W. Major feedstuffs used in swine diets. In: MILLER, E.R.; ULLREY, D.E.; LEWIS, A.J (Eds). Swine nutrition. 1.ed. Butterworth-Heinemann, 1991. p.509-516.

SILVA, D.J. Análise de alimentos (métodos químicos e biológicos). 1.ed. Viçosa, MG: Universidade Federal de Viçosa, 1990. 160p.

STANGELAND, V. Quality byproducts may replace added phosphorus. Feedstuffs, p.13, 1997.

UNIVERSIDADE FEDERAL DE VIÇOSA - UFV. SAEG Sistema de análises estatísticas e genéticas. Viçosa, MG: 1999. 150p. (Manual do Usuário).

VARNISH, S.A.; CARPENTER, K.J. Mechanisms of heat damage in proteins. 6 . The digestibility of individual amino acids in heated and propionylated proteins. British Journal Nutrition, v.34, p.339-349, 1975.

VIEITES, F.M. Valores energéticos e de aminoácidos digestíveis de farinhas de carne e ossos para aves. Viçosa, MG: Universidade Federal de Viçosa, 2000. 75p. Dissertação (Mestrado em Zootecnia) - Universidade Federal de Viçosa, 2000.

Recebido em: 17/10/03

Aceito em: 29/06/05 